\title{
Family Formation, Career Development, and Patriarchal Culture Hegemony: Study of Career Rhythms of Female Lecturers in Diponegoro University
}

\author{
Setyadi, Ary and Suyanto* \\ Faculty of Cultural Sciences, Diponegoro University, Semarang, Indonesia
}

\begin{abstract}
This paper aims to explain the relationship between family formation and the career rhythms of female lecturers. The sampling technique is cluster sampling, followed by the stratified random sampling technique. This study selected a sample of Universitas Diponegoro (Undip). The sample size calculation uses the Krejcie and Morgan technique. The number of respondents this study was 156 from 633 female lecturers of Undip. The results showed that 55 percent of women lecturers of Undip have been married for more than 10 years, 62 percent had 2-3 children, 53 percent as lector and associate professor in academic position, and only 1.9 percent as professors. Undip female lecturers transit time at expert assistant and lector is almost 15 percent and all professor when at associate professor are more than 7 years. Thus concluded that family formation was related with career rhythms. The shorter the age of marriage, the more children they have, the lower the age of the first and last child, will be slower of the career rhythm. This shows that Undip female lecturers cannot take advantage of the various opportunities and opportunities available for career development. This is more due to the outpouring of energy, mind and attention to family because children and families are more valuable than work for female lecturers. This is inseparable from the hegemony of patriarchal culture which is fertile and well-established in Indonesia in general and in Undip in particular.
\end{abstract}

Keywords: family formation, family and child, female lecturers, career rhythms, patriarchal culture

\footnotetext{
*Corresponding author: suyanto@live.undip.ac.id
} 


\section{Introduction}

In general, women when studies are more brilliant than men, but the condition is almost contrary to men when they are working [1]. With another statement, the condition of women between study and work as a brilliant educational biography to a poor occupational biography [2]. This fact is inseparable from the various obstacles of women, especially from the domestic sector related to family formation and its complexity in working in the public sphere. The biggest obstacle for women related to the domestic sector specially family formation is about children [3], sociocultural [4], and institutional and resource (structural) [5]. Women's careers, especially in tertiary education, at United Kingdom University and Slovenia are more than 80 percent of their professors are men [6], even in Semarang City, Indonesia, female professors are only 2.28 percent [7]. This condition is inseparable from the patriarchal culture which is the root of social relations that penetrates all aspects and lines of life.

Patriarchal culture is a form of organization that is dominated by the role of fathers. In that culture, a father dominates all family members and controls all aspects of life. Patriarchy includes the relationship of actors and institutions as male domination at the level of the individual to the level of society. This dominance comes from the ownership of wealth and income of men as the main source. In the end, patriarchy becomes an ideology. As an ideology, patriarchy operates by integrating itself with the cultural value system of the local community [8].

The family is the basis for the subordination of women by men because in the family the concept of property and servants were first used [9]. Although various efforts to eliminate discrimination against women are carried out, but not as a female lecturer in career development is equivalent to men. In line with this, the aim factor influencing the career rhythm of female lecturers is family and its complexity. Therefore, this paper focus on the relationship between the formation of the female lecturer family and her career rhythm.

In this paper, a career is defined as a series of roles, status, and position achieved by someone [10]. To measure a person's career development, career rhythm is used. Career rhythm illustrates how quickly someone steps up the career ladder and achieve certain beliefs $^{11}$, i.e. the period of achievement of a career event, which is related to the rank, position, level of education which has implications for the role given by the organization to him. Operationalization of career rhythm in the form of transit time, i.e. the period of achievement of events in career development whose operation is through the amount of time an individual needs to remain in a given position (a certain position) before advancing to the next position in the organizational career line [12]. This study framework observes the career rhythm of female lecturers linked to family formation which includes length of marriage, number of children, work migration.

The general shift of the family in the form of changes towards the well-being and happiness of life which is also the purpose of life in general. To achieve this, one way to do this is to improve the level of education and good work. Increasing education also means delaying marriage age, especially for women. By delaying the age of marriage, by itself will play a role in reducing fertility. Reducing fertility will play a role in family size, which is smaller. This fact will affect the changes in three aspects of family life, namely the extended family will shift to the nuclear family; the social and emotional role of the family shifts toward the economic role; and the occurrence of family individualization marked by infertility, single families, and cohabiting. According to Fratczak [13], family formation is closely related to cohorts, gender, place of birth, level of education, social background (parents' background: father's), occupation, age of marriage, and work migration. Formation of a family begins when the marriage is official. In this regard, it is necessary to emphasize formal marriage because in industrial societies, in addition to formal marriage it is common 
practice to live together without the bond of marriage (cohabitation), gay and lesbian family [14].

\section{Method}

The population in this research was all female lecturers at Diponegoro University ((Universitas Diponegoro-Undip) (633 female lecturers. Large sample collection in this study using Krejcie and Morgan techniques (156 female lecturer) [15]. The sampling uses cluster sampling techniques and stratified random sampling. The data obtained in this study are secondary data and primary data. Secondary data were obtained from the Agency of Planning and Information Systems (APIS) and the Bureau of Civil Service and General Administration. Primary data collection is done by several methods, namely: structured interviews and in-depth interviews. Data analysis uses quantitative and qualitative analysis. Quantitative analysis uses descriptive statistical analysis which is used to explain the trend of patterns and distribution of variable characteristics. Qualitative analysis uses descriptive analysis to explain the length of marriage, number of children, work migration.

\section{Results and Discussion}

Career rhythms are measured by (a) the duration of time required in the academic position of expert assistant; (b) the duration of time needed in the academic position of the lector; and (c) the duration of time required in the academic position of the associate professor. The three academic positions are the normative stages that must be passed to reach the top of the lecturer career ladder, namely professors. In this paper, family formations include length of marriage, number of children, and work migration.

\subsection{Length of Marriage}

Data shows, there is a relationship between long marriage and career rhythm shown by academic positions. The work period of 21 years or more normatively should have arrived at the academic position of the associate professor. Apparently, the data showed that respondents who had been married for 21 years or more were 48 people, meanwhile respondents who had reached the academic position of associate head numbered 52 people and 3 professors (overall 55 female lecturers). A more complete description of the respondent's marriage time is shown in the table below.

Table 1. Length of marriage of respondent

\begin{tabular}{|c|c|c|}
\hline Length of Marriage & Total of Respondent & Percentage \\
\hline 1-5 years & 30 & 19.1 \\
\hline 6-10 years & 18 & 11.5 \\
\hline 11-15 years & 22 & 14 \\
\hline 16-20 years & 16 & 10.8 \\
\hline$\geq 21$ years & 48 & 30.6 \\
\hline Total & 134 & 100 \\
\hline
\end{tabular}

Source: Primer Data, 20169. 


\subsection{Number of Children}

Another family formation factor closely related to the career rhythm of female lecturers is the number of children. Female lecturers generally have 2 children (33.56 percent), one and three children each 28.03 percent. The average number of children owned by female lecturers is 1.71 people. This figure is slightly higher than the average number of children per mother who has ever married in Semarang, which is $1.64^{16}$. The table below presents data on the number of respondents' children who were married (married, divorced, and divorced).

Table 2. Number of Respondent Children ever Married

\begin{tabular}{|c|c|c|}
\hline & \multicolumn{2}{|c|}{ Number of Respondent's Children } \\
\hline Number of children & Amount & Percentage \\
\hline No children & 13 & 8,90 \\
\hline 1 child & 38 & 28,03 \\
\hline 2 children & 49 & 33.56 \\
\hline 3 children & 38 & 28.03 \\
\hline$\geq 4$ children & 8 & 5.47 \\
\hline Total & 146 & 100 \\
\hline
\end{tabular}

Relatively significant respondents who have one child, in the future it is also likely to give birth to a second child and so the institution needs to answer it with a variety of policies that are friendly for women who are dependent on school-age children and infants, such as each faculty providing breast milk rumors day care for lecturers' children who have not yet entered school, and universities need to have Early Childhood Education or kindergarten (Pendidikan Anak Usia Dini-PAUD). At present, the Nursing Room is only provided by the Faculty of Medicine, Undip.

This implies the need for a woman-friendly policy, affirmative action for women. If there is no policy of this kind, there will be two possibilities, namely female lecturers in career development will be hampered or female lecturers whose careers will not be optimal in preparing their children to become the next generation of superior nation. With the current situation, there is no such woman-friendly policy, female lecturers seem to prefer slowing career rhythms rather than pursuing careers but families are victims, especially children. This finding is also in line with Partini's findings ${ }^{17}$. The data also shows that in each academic position, female lecturers have a very small percentage that can go up to four years or less. For example, in the position of associate professor, out of three lecturers who have exceeded him (professors), one person held that position for six years and two others seven or more years (see Figure 2). The number of female lecturers who have surpassed the academic positions of the lector is 55, 21 of whom have been in the office for seven years or more. Complete data on the duration of time required by female lecturers in each academic position (transit time) is presented in the figure below. 


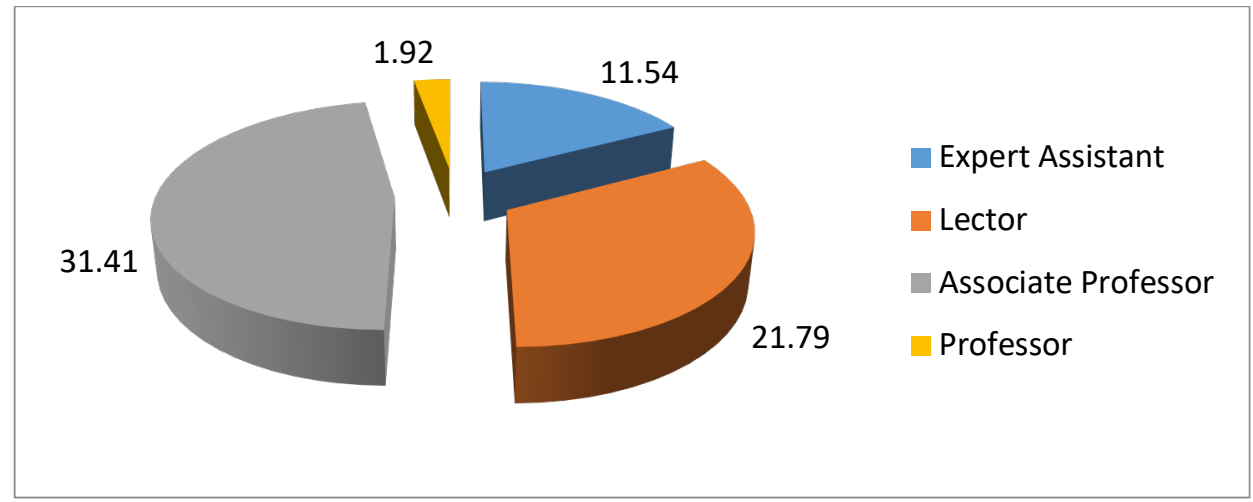

Fig. 1. Academic Position of Women Lecturers The Diponegoro University (Primer Data, 2019)

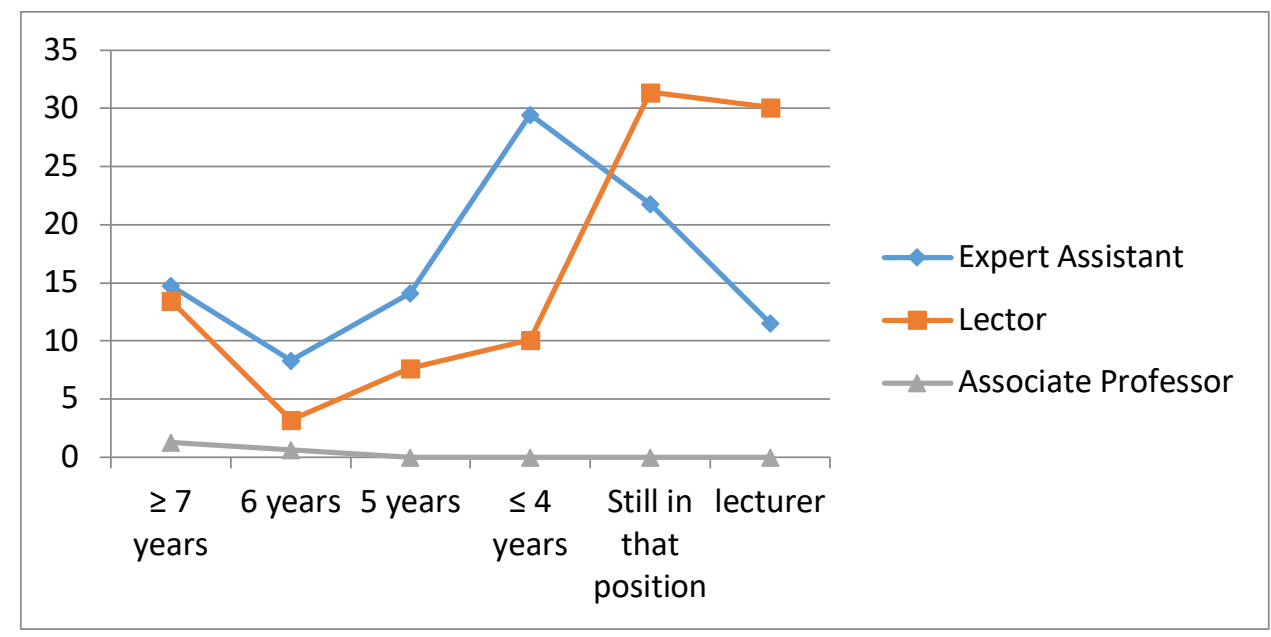

Fig. 2. Time Duration at each Academic Posistion (Primer Data, 2019)

\subsection{Work Migration}

According to Fratczack, work migration affects subsequent work, both positive and negative. Therefore, this study also analyzed the work migration of female lecturers ${ }^{18}$. The analysis showed that female lecturers before working as lecturers had worked 48.4 percent or 75 people and the rest had never worked, 51.6 percent or 81 people. Related to family formation, it was concluded that female lecturers, the shorter the length of marriage, the greater the number of children, the lower the age of the first and last child will slow down career rhythm. This finding is in line with Partini's research that for working women, family responsibilities especially those related to children become a major and influential obstacle $^{19}$. When faced with these obstacles, women generally choose to sacrifice their careers over families. Barometer of a woman's success is the success in educating and delivering her children to become successful people. This is the "ideal image and myth of the mother". In addition, the success of women in working in the public sector can be achieved if they receive support and encouragement from men (husbands). Thus, the success of women is not just as a woman's success itself but is the success of the family. 


\section{Conclusion}

The results showed that 55 percent of women lecturers of Undip have been married fo more than 10 years, 62 percent had 2-3 children, 53 percent as lector and associate professor in academic position, and only 1.9 percent as professors. Undip female lecturers transite time at expert assistant and lector is almost 15 percent and all professor when at associate professor are more than 7 years. Patriarchal culture is proven to still dominate female lecturers in developing their careers. This is what also happened in the career development of Undip female lecturers. The form of hegemony can be seen in the career rhythm of female lecturers which eventually accumulates at the rank level left behind by their peers, men on their way to the top of the lecturer career ladder, namely professors. In addition, the relationship of family formation and career rhythm of female lecturers is negative. If the shorter the age of marriage, the more children they have, the lower the age of the first and last child, the slower the rhythm of his career. Female lecturers in such conditions allocate more time to the family, especially children.

\section{References}

1. Gardiner, MO. Perempuan Indonesia: Dulu dan Kini. Jakarta: Gramedia (1996).

2. Marks, G and Diane M Houston. "The Determinants of Young Women's Intention about Education, Career Development, and Family Life". Journal of Education and Work. (2002), Vol.15, No.3 pp. 321-336.

3. Partini. Peluang Pegawai Wanita untuk Menduduki Jabatan Struktural: Suatu Studi pada Pegawai Negeri Sipil Pemda DI Yogyakarta". Disertasi untuk Memperoleh Derajat Doktor dalam Sosiologi pada Universitas Gadjah Mada Yogyakarta (1999).

4. Marhaeni, AAIN. "Tingkat Keberdayaan Perempuan Bali dalam Jabatan Eselon di Provinsi Bali: Ditinjau dari Dimensi Internal dan Eksternal", Disertasi untuk memperoleh Derajat Doktor Ilmu Kependudukan pada Universitas Gadjah Mada, 6 Oktober (2011).

5. Johnsrud, L K. "Administrative Promotion: The Power of Gender" in The Juornal of Higher Education, (1991) vol.62, No.2 (March/April).

6. Widyastuti, YSM dan Agung M Harsiwi. Produktivitas dan Kesempatan Aktualisasi Diri Dosen Perempuan. Laporan Penelitian dosen Muda (2004).

7. Suyanto. "The Woman Lecturer Career Patterns of State University at Semarang City: Life Cycle Approach" Dissertation of Population Studies, Universitas Gadjah Mada, Yogyakarta, Indonesia, Dipertahankan dalam Ujian Terbuka di Hadapan Dewan Penguji Sekolah Pascasarjana Universitas Gadjah Mada (2015).

8. Partini. Peluang Pegawai Wanita untuk Menduduki Jabatan Struktural: Suatu Studi pada Pegawai Negeri Sipil Pemda DI Yogyakarta". Disertasi untuk Memperoleh Derajat Doktor dalam Sosiologi pada Universitas Gadjah Mada Yogyakarta (1999).

9. Ritzer, G. Modern Sociological Theory, $4^{\text {th }}$ (eds.). New York: The McGraw-Hill (2004).

10. Hughes,E.C. Institutional Office and the Person. American Journal of Sociology, (1937), 43, pp.404-413.

11. Corona, VP. "Career Patterns in the U.S. Army Officer Corps". Springer (2010).

12. Ibid.

13. Fratczak, E. "Family, Fertility, and Migratory Careers of Polish Females" in Maria Eugenia Cosio-Zavala (ed.) Women and Families: Evolution of the Status of Women as a Factor and Consequence of Changes in Family Dynamics. UNFPA, Paris, 24-26 February (1997). 
14. Waite, LJ. "Marriage and Family" dalam Graziella Cazelli et al. (eds) Demograpy: Analysis and Synthesis. Amsterdam: Academic Press is Imprint Elsevier (2006).

15. Mantra, IB. Langkah-Langkah Penelitian Survai Usulan Penelitian dan Laporan Penelitian. Yogyakarta : Badan Penerbit Fakultas Geografi UGM (2000).

16. Biro Pusat Statistik.. Kota Semarang dalam Angka 2012 (2013).

17. Partini. Peluang Pegawai Wanita untuk Menduduki Jabatan Struktural: Suatu Studi pada Pegawai Negeri Sipil Pemda DI Yogyakarta". Disertasi untuk Memperoleh Derajat Doktor dalam Sosiologi pada Universitas Gadjah Mada Yogyakarta, pp xvi (1999)

18. Fratczak, E. "Family, Fertility, and Migratory Careers of Polish Females" in Maria Eugenia Cosio-Zavala (ed.) Women and Families: Evolution of the Status of Women as a Factor and Consequence of Changes in Family Dynamics. UNFPA, Paris, 24-26 February (1997).

19. Partini. Peluang Pegawai Wanita untuk Menduduki Jabatan Struktural: Suatu Studi pada Pegawai Negeri Sipil Pemda DI Yogyakarta". Disertasi untuk Memperoleh Derajat Doktor dalam Sosiologi pada Universitas Gadjah Mada Yogyakarta (1999). 